\title{
Detection of Legionella spp. and Other Pathogens in Water Systems of Nursing Homes and Spa Pools
}

\author{
Tanyaporn Kullaket ${ }^{1}$, and Tassanee Saovana ${ }^{2}$
}

\begin{abstract}
Legionella spp. are gram-negative and non-sporeforming bacteria. The Legionella infections are caused by the contaminated aerosols from the water distribution systems. The objectives of this study were to detect Legionella spp. and other bacterial pathogens in water systems of nursing homes and spa pools and to determine the relationship between water parameters and the prevalence of Legionella spp. The water samples were collected from nursing homes and spa pools and examined for the presence of Legionella spp. and other bacterial pathogens by culture methods. Legionella spp. was found in the water systems; 6 from 30 (20\%) of nursing homes and 13 from 30 (43.33\%) of spa pools. Other bacterial pathogens were Pseudomonas spp., Enterobacter spp., Acenetobacter spp. and Citrobacter spp.. There were no statistical significant correlation between water parameters $(\mathrm{pH}$ and temperature) and Legionella detection.
\end{abstract}

Keywords - Legionella spp., Nursing homes, Spa pools, Water systems.

\section{INTRODUCTION}

The Legionella spp. are gram-negative bacteria and short rod-shaped cells. The major representative species of the genus is Legionella pneumophila that can cause the Legionellosis [1]. Legionellae are commonly found in natural water environments (e.g., rivers, lakes, lagoon and reservoirs) and human-made water systems (e.g., cooling tower, water heater tanks, fountain and spa pools). The Legionellosis is divided into two distinct clinical entities, Pontiac fever which is a self-limited flu-like illness and has a high rate of infection of about 95\% and Legionnaires' disease which is a severe multisystem disease involving pneumonia with about $5 \%$ of infection but symptoms are more severe than Pontiac fever and may lead to death [2]. In Thailand, between 1984 to 2002, there were 17 patients reported to be infected with Legionella. Fourteen patients were infected by $L$. pneumophila, two patients were infected by Legionella spp. and another one was infected by L. jordanis. Legionella spp. has been isolated from human-made water systems and environmental samples in several regions of Thailand [3]. In 2006, there were Legionella infections in travellers at Phuket province.

Total 5 confirmed cases and 1 presumptive case were detected among all Scandinavians staying in the hotel at Phuket province. The risk factors of infection were showers in the hotels which had Legionella and people aged more than 45 years old had increased risk for Legionella spp. infection [4]. Other microorganisms that may be found in the water systems and can cause problems to human are gram-negative bacteria that are commonly found in soil, water and natural environments and may be found in the hospitals causing nosocomial infections. Most frequently reported microorganisms are Enterobacteriaceae, Pseudomonas aeruginosa, Staphylococcus aureus, coagulase-negative staphylococci and fungi which include Flavobacterium, Alcaligenes and Acinetobacter [5]. The purpose of this work is to study the prevalence of Legionella spp. and other bacterial pathogens in water systems of nursing homes and spa pools and to determine the relationship between water parameters and the prevalence of Legionella spp..

\section{PROCEDURE FOR PAPER SUBMISSION}

\section{A. Samples collection and processing}

Water samples from nursing homes and spa pools were collected approximately $500 \mathrm{ml}$ in the sterile containers and stored samples at room temperature during transporting to the laboratory. Each sample of water was collected in a sterile container which had $1 \mathrm{ml}$ of $10 \mathrm{mg} / \mathrm{ml}$ solution of sodium thiosulfate $\left(\mathrm{Na}_{2} \mathrm{~S}_{2} \mathrm{O}_{3}\right)$. The water temperature and $\mathrm{pH}$ were determined immediately after collection. The water samples were concentrated by filtration through $0.22 \mu \mathrm{m}$ pore size cellulose acetate membrane filters (Millipore S.p.A., Milan, Italy) and the membrane filters were cut into small pieces with aseptic technique, then put into a sterile tube that containing $1.5 \mathrm{ml}$ sterile distilled water and vortexed for 30 seconds to remove bacterial cells from the membrane filters.
Tanyaporn Kullaket 1 is with the Microbiology, Institute of Science, Suranaree University of Technology, (091-0204182; e-mail: jtk_chocolate@hotmail.com).
Tassanee Saovana2 was with the Microbiology, Institute of Science, Suranaree University of Technology, (e-mail: tassanee@sut.ac.th ). 


\section{B. Detection of Legionella species}

The $1.5 \mathrm{ml}$ of acid solution $(\mathrm{HCl}-\mathrm{KCl}$ solution $\mathrm{pH} 2.2)$ were added to the concentrated water samples for 5 minutes, then pipetted $1 \mathrm{ml}$ to another tube that already contained $9 \mathrm{ml}$ of sterile distilled water. The water samples were tested by spread plate technique at undiluted and $10^{-1}$ dilution, $0.1 \mathrm{ml}$ of each sample was placed in duplicate on Buffered Charcoal Yeast Extract (BCYE) agar and BCYE agar + glycine, vancomycin, polymyxin $\mathrm{B}$ and cycloheximide (GVPC), then incubated at $37^{\circ} \mathrm{C}$ in the humid chamber for 3-4 days. The suspect colonies were cultured on BCYE and BCYE without L-cysteine for testing the requirement of cysteine by streak plate technique and incubated at $35^{\circ} \mathrm{C}$ for 4 days.

\section{Isolation and quantitation of total heterotrophic plate} count

The water samples were analyzed by 10 -fold dilution series of the concentrate water samples. The samples were cultured duplicate on plate count agar (PCA) with spread plate technique. All plates were incubated at $35^{\circ} \mathrm{C}$ for $24-48$ hours . The number of colonies were counted and reported as colony forming unit per $\mathrm{ml}(\mathrm{CFU} / \mathrm{ml})$.

\section{Isolation of gram - negative bacteria}

The gram - negative bacteria were cultured by spreading 0.1 $\mathrm{ml}$ of sample on the Mac Conkey agar in duplicate. All plates were incubated at $35^{\circ} \mathrm{C}$ for 24 hours. The colonies of gram negative were identified by morphology and biochemical tests.

\section{E. Isolation of Staphylococcus spp.}

The isolation of Staphylococcus spp. was analyzed by spread plate technique on the selective medium, Manitol salt agar in duplicate. All plates were incubated at $35^{\circ} \mathrm{C}$ for 24 hours.

\section{F. Isolation of coliform and Escherichia coli bacteria}

The determination of coliform bacteria was analyzed by inoculate sample water to lactose broth and incubated at $35^{\circ} \mathrm{C}$ for 24-48 hours. The positive tubes had turbidity and produced gas within durham tube. The isolation of E.coli was analyzed by inoculated the positive tube to EC medium, streak plate on eosin methylene blue agar (EMB), confirm with urea test, Gram stain and catalase test.

G. Relationships between water parameters and the prevalence of Legionella spp.

The microbiological analysis was extended to the other information by investigated the relationship between Legionella spp. and other water quality parameters. The relationship was statistical analyzed by Pearson's correlation analysis.

\section{RESULTS}

From total of 60 water samples from nursing homes $(\mathrm{N}=30)$ and spa pools $(\mathrm{N}=30)$, they were found Legionella spp. in the water systems; 6 from 30 (20\%) of nursing homes and 13 from $30(43.33 \%)$ of spa pools. Total of 60 water samples sites were selected from showerheads, faucets and water tanks. The faucets were the most site that could be found Legionella spp. Other gram-negative bacteria were Pseudomonas spp., Enterobacter spp., Acenetobacter spp., and Citrobacter spp. The mean value of total plate count of nursing homes and spa pools were $5.26 \times 10^{4} \mathrm{cfu} / \mathrm{ml}$ and $4.33 \times 10^{4} \mathrm{cfu} / \mathrm{ml}$, respectively. The Staphylococcus spp. was found in the water systems; 9 from $30(30 \%)$ of nursing homes and 1 from $30(3.33 \%)$ of spa pools. The coliform bacteria, found in the nursing homes and spa pools, were 6 from 30 (20\%) and 4 from 30 (13.33\%), respectively and E.coli was found 2 from 30 (6.67\%) of nursing homes only. The mean value of $\mathrm{pH}$ was $7.32 \pm 0.07$ of nursing homes and $7.61 \pm 0.08$ of spa pools and mean value of temperature was $28.33 \pm 0.54^{\circ} \mathrm{C}$ of nursing homes and $27.10 \pm 0.50^{\circ} \mathrm{C}$ of spa pools. The relationship between water parameters $(\mathrm{pH}$ and temperature) and the prevalence of Legionella spp. had no statistical significant correlation in nursing homes $(\mathrm{pH}, \mathrm{r}=-0.282$ and temperature, $\mathrm{r}=-0.010$ at $\mathrm{p}<$ $0.05)$ and also in the spa pools $(\mathrm{pH}, \mathrm{r}=0.255$ and temperature, $\mathrm{r}$ $=0.089$ at $\mathrm{p}<0.05)$.

\section{DISCUSSIONS}

The total of 60 water samples from nursing homes and spa pools were cultured for Legionella spp. and 19 of them were positive (31.67\%). The number of positive samples for Legionella spp. in this study was similarly to other studies in Thailand. The prevalence of Legionella spp. in water systems of hotels and resorts in the North-Eastern of Thailand was 24 from 75 (32.0\%) hotels and resorts [6]. During 2003-2007, the prevalence of Legionella spp. in various water resources from 33 provinces in Thailand were investigated and 256 Legionella strains were isolated, among these, 206 isolates (80\%) were belonged to L. pneumophila and 50 isolates were identified as non-pneumophila by DNA tree analysis [7]. In 2004, Triassi et al. studied Legionella infection risk from domestic hot water [8] and found $22.6 \%$ (33/146) Legionella spp. and $38.4 \%$ (56/146) Pseudomonas spp.. Naturally occurring $L$. pneumophila multiplied at a temperature between $25^{\circ} \mathrm{C}-37^{\circ} \mathrm{C}$ and $\mathrm{pH}$ levels of $5.5-9.2$, [9] and the average mean of $\mathrm{pH}$ and temperature of this study was in standard value of Queensland health swimming and spa pool water quality and operational guidelines 2004 which were between $7.2-7.8$ and $35^{\circ} \mathrm{C}-37^{\circ} \mathrm{C}$ [10]. In part of nursing homes, the positive sites may be risk to the elderly or intendants that stay there. But the elderly age over 60 years included smokers have more risk than the other people because they have low immunity and the Legionella infection was found in male more than female [11]. In part of spa pools, the positive sites may be risk to the customers and spa pool keepers. The route of infection can transmit by inhalation of bacterial contaminated aerosols. Therefore, the result of this study should be concerned by the epidemiologists since Legionella spp. and other bacterial 
pathogens may be cause of the possible outbreak of Legionellosis and other bacterial pathogens in the water systems.

\section{REFERENCES}

[1] S. L. Percival, and D. W. Williams, "Chapter Eight Legionella," Microbiology of Waterborne Diseases (Second Edition), pp. 155-175, London: Academic Press, 2014. https://doi.org/10.1016/B978-0-12-415846-7.00008-1

[2] B. S. Fields, R. F. Benson, and R. E. Besser, "Legionella and Legionnaires' disease: 25 years of investigation," Clinical microbiology reviews, vol. 15, no. 3, pp. 506-526, 2002. https://doi.org/10.1128/CMR.15.3.506-526.2002

[3] Bovornkitti S. (2010). "Legionella". Thammasat Medical Journal 9: 436-41.

[4] R. Buathong, R. Prasarnthong, W. Seetamanotch, T. Natewong, T. Saowarun, K. Chanthayanee, N. Marin, D. Sutdan, T. Ouppapong, and S. Iamsirithaworn, "Travel-associated Legionnaires Disease Outbreak among EU Travelers, Phuket Thailand, December 2006 to January 2007: Role of Environmental Investigation," Weekly Epidemiological Surveillance Report, vol. 44, no. S, pp. S38-S46, 2013.

[5] J.-L. Vincent, D. J. Bihari, P. M. Suter, H. A. Bruining, J. White, M.-H. Nicolas-Chanoin, M. Wolff, R. C. Spencer, and M. Hemmer, "The prevalence of nosocomial infection in intensive care units in Europe: results of the European $\mathrm{Pr}$ evalence of Infection in Intensive Care (EPIC) Study," Jama, vol. 274, no. 8, pp. 639-644, 1995.

https://doi.org/10.1001/jama.1995.03530080055041

[6] A. Mahayotha, T. Butkot, P. Wongveerakhant, V. Prasartthong, U. Punthanaprated, P. Cheuypratoom, T. Ruengwittayanon, A. Saentaweesuk, S. Tongkliang, and W. Jamsai, "Legionella spp. Surveillance Network, North-eastern of Thailand (เครือ ข่าย การ เฝ้า ระวัง การ แพร่ เชื้อ Legionella spp. ภาค ตะวันออก เฉียง เหนือ ของ ประเทศไทย)," Journal of Health Science-วารสาร วิชาการ สาธารณสุข, vol. 25, no. 5, pp. 929-934, 2016.

[7] W. Paveenkittiporn, S. Dejsirilert, and T. Kalambaheti, "Genetic speciation of environmental Legionella isolates in Thailand," Infection, Genetics and Evolution, vol. 12, no. 7, pp. 1368-1376, 2012. https://doi.org/10.1016/j.meegid.2012.03.025

[8] M. Triassi, P. Borella, M. Montagna, V. ROMANO-SPICA, S. Stampi, G. Stancanelli, R. Neglia, I. Marchesi, G. Fantuzzi, and D. Tato, "Legionella infection risk from domestic hot water," Emerging infectious deseases, vol. 10, no. 3, pp. 457-464, 2004.

[9] R. M. Wadowsky, R. Wolford, A. McNamara, and R. B. Yee, "Effect of temperature, $\mathrm{pH}$, and oxygen level on the multiplication of naturally occurring Legionella pneumophila in potable water," Applied and environmental microbiology, vol. 49, no. 5, pp. 1197-1205, 1985.

[10] Government Q, "Queensland health swimming and spa pool water quality and operational guidelines 2004". Brisbane, QLD: Bibliography, 2004, pp.52.

[11] P. Elverdal, C. Jørgensen, K. Krogfelt, and S. Uldum, "Two years' performance of an in-house ELISA for diagnosis of Legionnaires' disease: Detection of specific IgM and IgG antibodies against Legionella pneumophila serogroup 1, 3 and 6 in human serum," Journal of microbiological methods, vol. 94, no. 2, pp. 94-97, 2013. https://doi.org/10.1016/j.mimet.2013.04.010

First Author: Tanyaporn Kullaket

Address is 797 M.1 Petcharamatukala Road, Huatalae Sub-District, Muang District, Naknonratchasima Province, Thailand. The telephone number is 091-0204182 and E-mail is jtk chocolate@hotmail.com. Nationality is Thai and date of birth on September 10, 1989. Education/Qualification; Bachelor of Science: veterinary technology (GPA: 3.25) Second-class honor, Kasetsart University (2008-2011) and Master of Microbiology: Instruction Scholarship under Institute of science Suranaree University of Technology (2013-Present).

Experience; Veterinary Technician in Thai Vet Laboratory Limited Company at Bangkok Province (2012-2013) and Teacher Assistant (TA) in Microbiology and Biology at Suranaree University of Technology (2013-Present). The Interested research is about Microbiology. 